\title{
A study of Career Development needs of Moroccan University Students
}

\author{
Oussama Ait Tejan*, Abdelkader Sabil
}

Faculty of Letters and Human Sciences, University Hassan II, Ben Msik Casablanca, Morocco

*Corresponding author: oussama.tejan@gmail.com

\begin{abstract}
This paper addresses the issue of career development needs of Moroccan university students. It argues that in a saturated and continuously changing labormarket, be it private or public, Moroccan University graduates need to be informed and prepared for the newly required labor exigencies. To account for this situation, this study utilizes (SCCT) as a theoretical framework. It also deploys a quantitative approach. The findings of this study have it that Moroccan universities should grant more importance to career development in their syllabi. Therefore, the study recommends that Moroccan universities should allocate more resources towards career development.
\end{abstract}

Keywords-Career, Career development, University students, Morocco, Social Cognitive Career Theory, employment, employees, graduates.

\section{INTRODUCTION}

Employment trends and needs in Morocco have greatly changed in the recent past years, with limited opportunities in both the public and private sectors. This has forced many university graduates to seek career opportunities in the private sector. However, the private sector also has limited opportunities and nearly 23\% of graduates each year remain unemployed (Koundouno, 2018).The inconsistency between skills and competencies of job seekers and the requirements of private sector employers create a significant challenge. According to FHI 360 (2018) companies are looking for skills and competencies, not degrees. Therefore, it is important for graduate students to understand their individual skill set and the way they can effectively apply their abilities to employers. FHI 360 (2018) adds that university students should not think about what they lack, rather they should focus on the skills they have to further strengthen and develop them.

USAID (2018) acknowledges the issue of career development by underlining that many graduates are unable to effectively communicate with their employers, which hinders them from getting employed. Similarly, employers point out of skills mismatch and shortage, underlining the importance of career development and counseling. To this end, the Moroccan government through the ministry of higher education has collaborated with several organizations that include USAID and IREX to create career centers. For example, one career center was built in partnership with USAID Morocco and the Ministry of Higher Education and is available at Cadi Ayyad University in Marrakech.

The opening of these centersarose from the fact that most of Moroccan public universities are overcrowded with limited resources to adequately prepare students for employment after they graduate. Through this center and others, university students are supported to better respond to the changing needs and trends of the labor market. They also seek to link students with meaningful competencies and knowledge required to succeed in the labor market.

Youth employability is important because since young people who will drive economic and social growth of the country. However, improving their employability begins by enhancing information and access to career development. This entails training as well as equipping university students with work readiness skills.

\section{THEORETICAL FRAMEWORK}

To examine the career development needs of Moroccan University students, Social Cognitive Career Theory (SCCT) is applied to explain the way the various variables can result in a successful career. As mentioned by Lent \& Brown (1996), this theory originates from Bandura's Social Cognitive Theory. Accordingly, the theoretical framework details how variables such as personal goals, self-efficacy, and outcome expectations 
interact with external variables like the environment of the individual and gender either to promote or constrain career growth and development.

SCCT underlines that there are three intertwined variables that influence or regulate an individual's career behavior and development, namely, self-efficacy, personal goals, and outcome expectations (Lent \& Brown, 1996). According to Bandura, self-efficacy is a personal judgment of an individual regarding his or her abilities to perform certain tasks in order to achieve desired outcomes (Lent \& Brown, 1996). The outcome expectations are individual beliefs held regarding the results of his or her actions. Lent \& Brown (1996) explains that individuals assess the likely impact of particular behaviors, and this is applicable in the workplace situation. Outcome expectations are concerned with a person's experiencesand second-hand information that the individual receives regarding a certain situation. For example, a junior manager might expect a promotion to senior management level based on his or herexperiences and the promotion practices of the organization.

Personal goals are the most central, and they are more solid compared to the belief system applied in outcome expectations and self-efficacy. Personal goals determine how individuals organize, sustain and guide their individual efforts even though there is no external assistance (Lent \& Brown, 1996). The way these three variables interact assist in controlling career behavior and therefore career development. Below is a diagram of SCCT showing the various variables that influence career development?

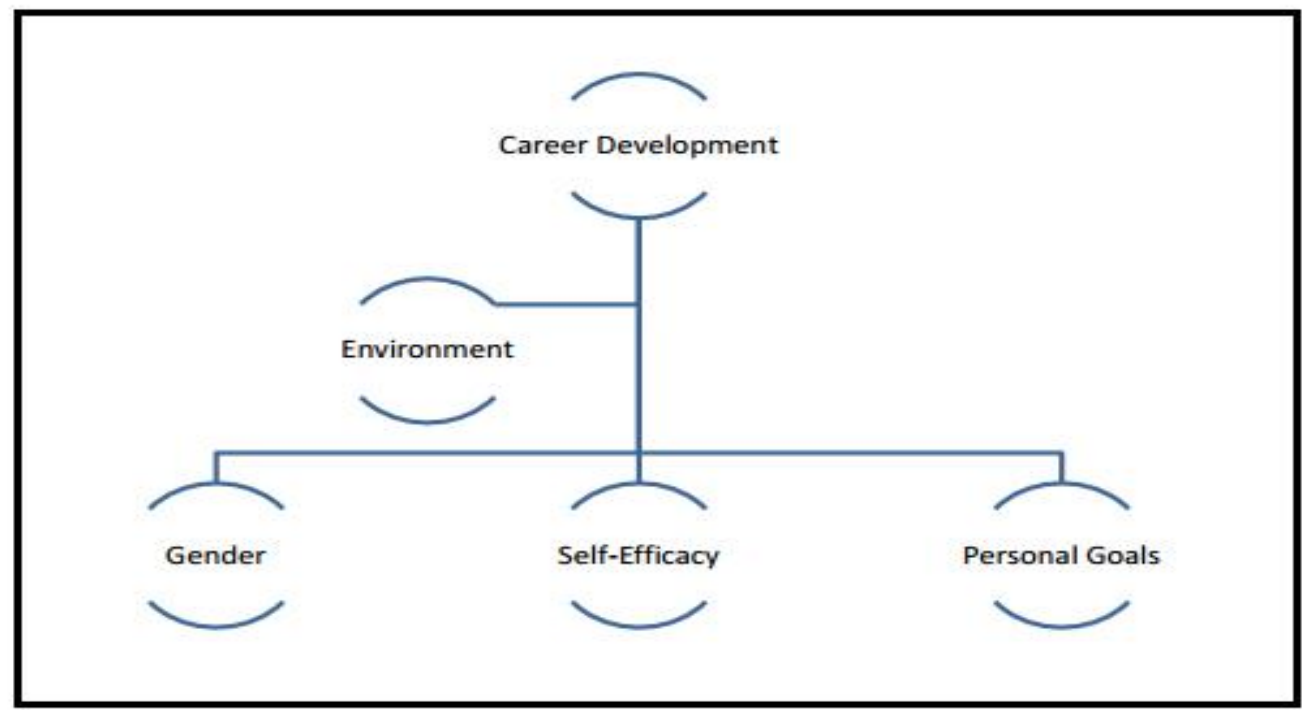

Diagram 1: Social Cognitive Career Theory (adapted from Lent \& Brown, 1996).

\section{LITERATURE REVIEW}

Over the past years, there has been a significant change in the Moroccan workforce with the entry of more university graduates into the labor market. The percentage of female graduates has increased from $11 \%$ in 2000 to $32 \%$ in 2016 (World Bank, 2018). This illustrates the progress that has been made in higher learning education in terms of increasing the number of graduate students. As observed by Koundouno (2018) Moroccan universities awarded nearly 60,000 BA degrees in 2017. Nonetheless, the graduates who joined the job market found out that there were thousands of unemployed BA degree holders or even higher (Koundouno, 2018). The current growth of employment has seen nearly $22 \%$ of the graduates remain unemployed each year (USAID, 2018). This is because of the few job offers from employers who require specific employability skills.

Rasul, et al (2012) observes that the current job market is more complex compared to the past. Today, the job market entails aspects such as more pronounced differences in opinions held by graduates towards career, learning, and work. The rate of transformation in today's labor market is high owing to rapidly changing human resource management practices. Rasul, et al (2012) suggests that higher education must strengthen its link with the corporate world to make sure that graduate students understand the changes in the labor market, and to assist graduates to develop specific skills required by employers. It is equally important that employers inform universities and university students about the skills they are looking for. 
Brown (2015) noted that advancement entering into employment particularly at the managerial level can only occur through career development. Brown (2015) goes on to explain that career development is the change or changes that happen in a person's career. Nonetheless, it is worth noting that not all career changes are developmental or progressive. Career development applied in this study borrows the definition of White, Cox \& Cooper (1992) that refers to planned and successive changes in a person's professional life indicating advancement. The changes that occur are represented by the hierarchical ascending of the famed corporate ladder, greater freedom, and higher salaries, thereby developing an individual's career, high respect, and increased recognition.

As observed by Eisner (2010) the relationship existing among employers, universities and students is complicated and depend on the level of engagement that the graduates show regarding the available opportunities to develop their career. Eisner (2010) asserts that universities can offer a path to employment by offering appropriate workplace skills, attitudes and knowledge that employer's value. Presently, university students in Morocco face high competition from experienced workers, a low rate of employment, changing skill demands by corporates and progressively prevailing global labor force resulting in increased uncertain and challenging labor market. The realities of the current labor market underline the significance of career development stressed by educators and practitioners in establishing different attributes that university graduates should possess to meet the requirements of employers in the current workplace.

Zulkosky (2009) explains that the concept of selfefficacy was applied by Bandura as aprimary concept in Social Cognitive Theory. This concept underlines individuals' beliefs about their abilities to perform at certain expected levels (Bandura, 1994). Accordingly, this implies that a person has to understand his or her self-efficacy and depend on his or her perceptions and beliefs. The person has to get involved in the act of self-appraisal to form their capabilities and abilities. Though there is enough evidence that high education can increase opportunities for jobs, the unemployment rate remain high for graduates in underdeveloped and developing countries like Morocco (Baciu and Lazar, 2011). Studies done indicate that there is a gap between the needs of employers and the qualifications of graduates. Baciu and Lazar (2011) noted that students lack experience to the realities of the labor market. Furthermore, there is inconsistency in the amount of demand in the labor market and the available graduates with suitable employability skills and competencies.

Organizations or employers also hold the wrong belief that university graduates usually lack the nontechnical or soft skills required for employment. This makes graduates remain unprepared for the labor market (Ramakrishnan and Yasin, 2010). Likewise, findings by Bhanugopan and Fish (2009) on graduate employability underline the importance of having similar perceptions between employer and graduates regarding employability skills. Bhanugopan and Fish (2009) found that employers view graduates as lacking employability skills required by their organizations. The findings further noted that employers viewed graduates as lacking suitable personal attributes and general business competencies needed to sufficiently prepare them for employment. As such, employers view graduates as not having the employability skills needed to successfully complete certain tasks (Bhanugopan and Fish (2009).

In a related study, Rao et al (2011) found that there was a gap between employability skills and competencies of graduates and employerrequirements. Specifically, it was established that employers usually select graduates that have a practical understanding of organizational environment and better presentation skills (Rao et al, 2011). These findings underline the importance of career development among graduates to better prepare them for the future job market.

\section{METHODOLOGY}

Research design as explained by Stangor (2011) is the method applied by a researcher to collect, analyze and interpret data. This implies that it is the work plan or structure that allows the research questions to be answered. Owing to the objective of this study that is examining the career development needs of Moroccan University students, the research design takes a quantitative approach to enable the researcher to answer questions regarding the current situation of affairs. As noted by Creswell (2013) quantitative approach is well suited for exploring reasons why individuals make certain choices. For example, in the current study that seeks to understand career development needs of Moroccan university students, a closed-ended questionnaire is used to provide answers that need to be statistically analyzed. Accordingly, the questionnaire was used to assess career development needs of Moroccan University students. The questionnaire was developed and 
sent to university students. Data was ascertained and later analyzed using statistical means.

Instrument

Questionnaires wereused as a data collection instrument. These questionnaires were authenticated and piloted before being distributed. The questions in the questionnaires were adopted from the literature review and the research objectives of the study(Kothari, 2004). The questionnaires were selected as data collection because they are effective in measuring attitudes, viewsand intentions. Thus, it is relevant in obtaining the views of Moroccan university students regarding career development needs.

Study population

The study population of the present study comprised of university students in Cadi Ayyad University including the faculty of arts and humanities and the faculty of economics and law. 150 students were asked to take part in the study by filling the questionnaires, which were emailed to them. Theyhad ten days to fill and email back the questionnaires. A total of 48students successfully completed the questionnaires.

Data Analysis

After collecting the data, it was checked for reliability and verification, before being analyzed using quantitative techniques namely (SPSS). Accordingly, data was coded, analyzedusing statistical means. Frequencies and percentages of responses were presented for better and easy understanding.Charts were incorporated in analyzing pers onal information of respondents.

\section{FINDINGS}

Personal information of the respondents

\section{Gender of the Respondents}

Majority of the respondents were male with $68.75 \%$ compared to female who made up $31.25 \%$ of total respondents.

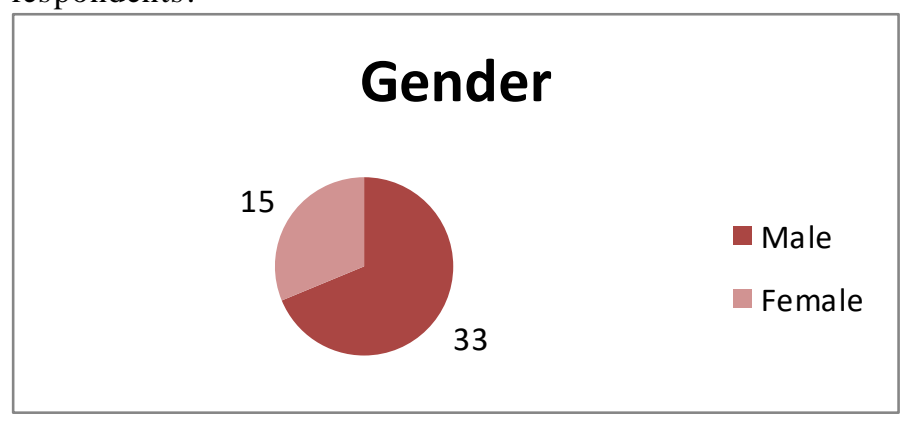

Fig.1: Gender

Age of the Respondents
The respondents who took part were aged between 18 and 41 years old, the majority were aged 18-25 years old and made up more than two thirds of the respondents. Those aged between 34-41 years old were the least with $10 \%$ of the total respondents.

\section{Age group of participants}

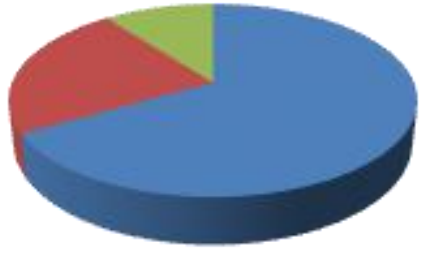

18 - 25 years old

26 - 33 years old

34 - 41 years old

Fig.2:Age group of participants

Current Academic Year

Majority of the respondents were in their third year of study, with those in their first year of study forming a considerable percentage as shown in the table below. Other years of study were represented in the respondents who took part in the study.

\section{Academic year of respondents}

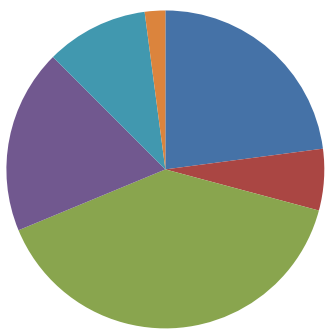

First Year

Second Year

Third Year

Fourth Year

Fifth Year.

Fig.3: Academic year of respondents

\section{Career Development}

On employee Training, most of the respondents $97 \%$ agreed that employee training is important in career development. Only $2.8 \%$ remained neutral. When asked about skill acquisition, the respondents either agreed or strongly agreed on the importance of skill acquisition. Indeed, $43 \%$ agreed that skill acquisition is important in career development, while $56 \%$ strongly agreed. When asked how self-efficacy determines the performance of their job roles, $45.83 \%$ 
strongly agreed that self-efficacy determines their job performance, while $35.42 \%$ agreed, $14.58 \%$ remained neutral and $4.17 \%$ disagreed. All of those interviewed agreedthat outcome expectations played a key role in influencing their career development.

When asked about personal goals' influence on their career development, $56.25 \%$ of the respondents strongly agreed that personal goals had an influence, while $43.75 \%$ agreed. On creation of opportunities, $31.25 \%$ agreed that career development created opportunities. Majority of the respondents agreed that career development enabled employees in determining their career path $43.75 \%$ agreed, and $47.92 \%$ strongly agreed. However, $8,33 \%$ were neutral on whether career development helped employees to form a proper career path.
Respondents were in agreement that soft skills were important in career development with $37.50 \%$ agreeing and $62.50 \%$ strongly agreeing. On university and career training, most of the respondents elicited mixed reactions on whether the university recognized the need for career training of the students within the learning institutions. Accordingly, $10.42 \%$ disagreed, $45.83 \%$ remained neutral, $35.42 \%$ were in agreement and only $8.33 \%$ strongly disagreed. The respondents had mixed responses on whether the resources allocated by the university on career development were adequate, $16.67 \%$ disagreed, $60.42 \%$ were neutral and $22.92 \%$ agreed. All these findings are represented in the table below.

Table 1: Findings

\begin{tabular}{|c|c|c|c|}
\hline Variable & Value Label & Frequency & Percent \\
\hline \multirow[t]{3}{*}{ Employee Training } & Neutral & 1 & 2.08 \\
\hline & Agree & 13 & 27.08 \\
\hline & Strongly Agree & 34 & 70.83 \\
\hline \multirow[t]{2}{*}{ Skill acquisition } & Agree & 21 & 43.75 \\
\hline & Strongly Agree & 27 & 56.25 \\
\hline \multirow[t]{4}{*}{ Self-efficacy } & Disagree & 2 & 4.17 \\
\hline & Neutral & 7 & 14.58 \\
\hline & Agree & 17 & 35.42 \\
\hline & Strongly Agree & 22 & 45.83 \\
\hline \multirow[t]{2}{*}{ Outcome expectations } & Agree & 14 & 29.17 \\
\hline & Strongly Agree & 34 & 70.83 \\
\hline \multirow[t]{2}{*}{ Personal goals } & Agree & 21 & 43.75 \\
\hline & Strongly Agree & 27 & 56.25 \\
\hline \multirow[t]{2}{*}{ Creation of Opportunities } & Agree & 15 & 31.25 \\
\hline & Strongly Agree & 33 & 68.75 \\
\hline \multirow[t]{3}{*}{ Creates a Career Path } & Neutral & 4 & 8.33 \\
\hline & Agree & 21 & 43.75 \\
\hline & Strongly Agree & 23 & 47.92 \\
\hline \multirow[t]{2}{*}{ Soft Skills } & Agree & 18 & 37.50 \\
\hline & Strongly Agree & 30 & 62.50 \\
\hline \multirow[t]{4}{*}{ University and Career Training } & Disagree & 5 & 10.42 \\
\hline & Neutral & 22 & 45.83 \\
\hline & Agree & 17 & 35.42 \\
\hline & Strongly Agree & 4 & 8.33 \\
\hline \multirow[t]{3}{*}{ Resources to career development } & Disagree & 8 & 16.67 \\
\hline & Neutral & 29 & 60.42 \\
\hline & Agree & 11 & 22.92 \\
\hline
\end{tabular}




\section{DISCUSSION}

There has been a remarkable change in the Moroccan workforce for the recent past years because of the increased number of graduates in the job market. Studies have shown getting to employment particularly at the management level requires proper career development (Brown, 201). This observation seems to align with findings from the survey where respondents agreed that career development is necessary in pursing one's career goals, employee training is also important since it gives the employee more skills and therefore opportunities to advance in his or her career. Moroccan universities play a central role in career development. Personal goals and self-efficacy are important in career development because they influence the career decisions of a person (Lent \& Brown, 1996).

As noted by Eisner (2010) universities can offer a path to employment by offering appropriate workplace skills, attitudes and knowledge that employers value. Students who undergo career development have higher chances of getting employed because it opens their career path. However, there is a certain agreement among respondents that universities lack the appropriate resources or they have not allocated enough resources towards career development of their students. This situation implies that some of the graduates from those universities are not well equipped to compete in the labor market.

\section{CONCLUSION}

The present study aimed at analyzing career development needs of Moroccan University students. The study has revealed that Moroccan graduates require career development to compete well in the labor market that has become highly competitive. Most of our universities need to make greater efforts to provide enough resources in terms of career counselors who can guide students towards the right career path. However, the belief and self-efficacy held by students as well plays an important role in determining their career path. Graduates who have high level of self-efficacy are able to see opportunities and hold more optimistic views to pursue their careers. Today's companies are more interested in the skills and competencies compared to degrees. Therefore, it is important that universities equip their graduates with the necessary skills that are sought by employers. In view of the above findings, the study recommends that Moroccan universities should continue to collaborate with private and non-governmental organization such as USAID in creating career centers to offer career development opportunities to students. Universities also need to allocate more resources for career development activities.

\section{REFERENCES}

[1] Baciu, E. and Lazar, T. (2011) Skills Supply and Skills Demand Among Youth: Object of Concern or Object of Hope? Revista De Asistenta Sociala, 4, 85-101

[2] Bandura, A. (1994). Self-Efficacy. Encyclopedia of human behavior, 4, 71-81.

[3] Bhanugopan, R. and Fish, A. (2009) Achieving Graduate Employability through Consensus in the South Pacific Island Nation. Education + Training, 51, 108-123.

[4] Brown, D. (2015). Career Information, Career Counseling, and Career Development. Pearson

[5] Creswell, J. W. (2013). Research design: Qualitative, quantitative, and mixed methods approaches. Sage Publications, Incorporated.

[6] Eisner, S. (2010) Grave New World? Workplace Skills for Today's College Graduates. American Journal of Business Education, 3, 27-50.

[7] FHI 360. (2018, November 2). Career counselor plays critical role as Moroccan university students seek jobs. Retrieved from https://www.fhi360.org/news/careercounselor-play s-critical-role-moroccan-university-studentsseek-jobs

[8] IREX (2016). Helping youth pursue meaningful employ ment in Morocco. (n.d.). Retrieved from https://www.irex.org/news/helping-youth-pursuemeaningful-employment-morocco

[9] Kothari, C. R. (2004). Research methodology: methods and techniques. Dehli: New Age International.

[10] Koundouno, T F (2018).Lahlimi: One-Third of Moroccan Graduates Are Unemployed.Retrieved from https://www.moroccoworldnews.com/2018/08/251778/lahli mi-one-third-of-moroccan-graduates-are-unemploy ed/

[11] Lent, R. W, \& Brown, S. D. (1996). Social cognitive approach to career development: An overview. The Carer Development Quarterly. 44(4), 310-321.

[12] Ramakrishnan, K. and Yasin, N.M. (2010) Knowledge Management Portal: Connecting Higher Learning Institution and Employer. Journal of Data Mining and Knowledge Discovery, 1, 1-18.

[13] Rao, A., Shah, S., Aziz, J., Jaffari, A., Ejaz, W., Ul-Haq, I. and Raza, S. (2011) Employ ability in MNCs: Challenge for Graduates. Interdisciplinary Journal of Contemporary Research in Business, 3, 189-200

[14] Rasul, M.S., Rauf, R.A.A., Mansor, A.N. and Puvanasvaran, A.P. (2012) Employability Skills Assessment Tool Development. International Education Studies, 5, 43-56

[15] Stangor, C. (4th Ed.). (2011). Research methods for the behavioural sciences. United States: Wadsworth Censage Learning. 
[16] USAID. (2018, July 17). CAREER CENTER MOROCCO.

Retrieved from

https://www.youthpower.org/sites/default/files/YouthPower /resources/USAID\%20Career\%20Center\%20M orocco-

Webinar\%20Powerpoint-Final.pdf

[17] World Bank. (2018). Gender Data -Morocco. Retrieved from http://datatopics.worldbank.org/gender/country/morocco

[18] Zulkosky, K. (2009). Self-Efficacy : A Concept Analysis. Nursing Forum, 44(2), 93-102 